\title{
Community Knowledge and Attitudes about the Transmission of Dengue Haemorrhagic Fever and Its Relationship to Prevention Behaviour in Palembang, South Sumatra, Indonesia
}

\author{
Minarti Minarti ${ }^{1}$, Chairil Anwar ${ }^{2 *}$, Irfannuddin Irfannuddin ${ }^{3}$, Chandra Irsan ${ }^{4}$ \\ ${ }^{1}$ Department of Environmental Science, Graduate School, Universitas Sriwijaya, Palembang, Indonesia; ${ }^{2}$ Department of \\ Parasitology, Faculty of Medicine, Universitas Sriwijaya, Ogan Ilir, South Sumatra, Indonesia; ${ }^{3}$ Department of Physiology, \\ Faculty of Medicine, Universitas Sriwijaya, Indralaya, South Sumatra, Indonesia; ${ }^{4}$ Department of Plant Protection, Faculty of \\ Agriculture, Universitas Sriwijaya, Ogan Ilir, South Sumatra, Indonesia
}

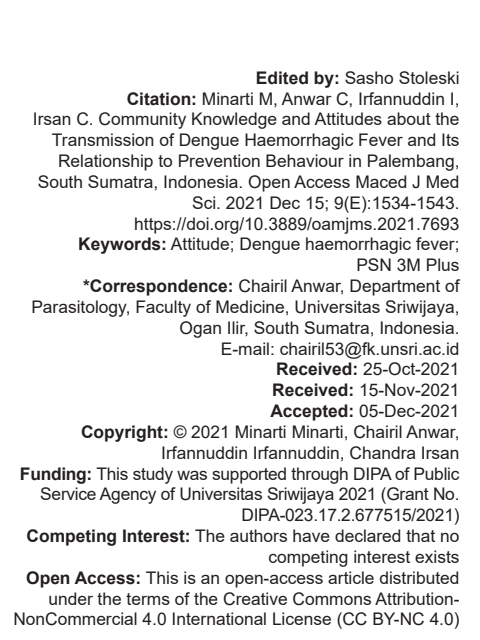

\section{Abstract}

BACKGROUND: PSN 3 M Plus is a long-running program in Indonesia for the prevention and control of dengue hemorrhagic fever (DHF).

AIM: This study aimed to determine the knowledge, behavior, attitudes, and beliefs of the community toward PSN 3 $\mathrm{M}$ Plus in preventing and controlling the spread of DHF.

METHODS: A cluster random sampling method was used to recruit 200 respondents in endemic areas and 100 respondents in sporadic locations of Indonesia from August 2020 to February 2021. The respondents were interviewed directly by interviewers and the relationships between demographics and characteristics with the practice of PSN 3M Plus prevention behavior on the incidence of DHF were analyzed.

RESULTS: Most respondents had good knowledge regarding the cause of DHF. Although respondents recognized and understood the dangers of and how to control DHF, most did not follow PSN 3 M Plus and believed that fogging was the most effective control measure. There was a significant relationship between the characteristics of the respondents in terms of education, occupation, and attitude on vector control practice.

CONCLUSION: Although community environmental modifications can be a cost-effective approach to reduce the incidence of DHF, there is a need to raise public awareness regarding preventive vector control measures as good knowledge does not guarantee good compliance with PSN 3M Plus recommendations.

\section{Introduction}

Dengue hemorrhagic fever (DHF) is the most common arboviral disease globally [1], affecting more than 100 countries, both tropical and subtropical [2], with an estimated 390 million dengue virus infections annually [3], of which, 96 million manifest clinically [4]. The virus is transmitted by the Aedes aegypti mosquito [5], [6], which rapidly breed in urban environments [7]. The World Health Organization recommends a community-based integrated vector control approach to combat $A$. aegypti. For this strategy to be effective, the authorities need to ensure that local communities have sufficient knowledge about vector control and are willing to act according to the recommendations [7]. Currently, vector control is the only available method to control DHF as there is no specific treatment or vaccine yet available for DHF [8]. An integrated vector control strategy is important [9], with DHF prevention and control achieved through environmental management and behavior change [10].
Knowledge and behavior greatly influence the dynamics of the Aedes mosquito population, which in turn affects dengue virus transmission [11]. Vector control is critical [12], with knowledge and behavior being fundamental aspects of DHF control and prevention [13]. Currently, the recommended control measure is the eradication of mosquito breeding nests [14], however, the local community needs to have a good understanding of the routes of DHF transmission of DHF, as their behavior plays a vital role in limiting dengue disease transmission [15].

The vector control program in Indonesia was introduced in 1992 through the 3M movement, namely drain, Bury, Cover. Since 2000, the program has been modified to $3 \mathrm{M}$ Plus with larvicides, raising fish in small ponds/puddles and preventing mosquito bites using mosquito repellents. This program aims to change people's behaviour [16] and eradicate mosquito nests to prevent dengue and control mosquito breeding grounds [17]. For success, the program must be accompanied by awareness-raising campaigns and 
community participation [18]. Knowledge, Attitude, and Practice surveys [19] suggest that dengue control is difficult to achieve due to low community motivation, therefore, it is challenging for health campaign teams to convince the public of the importance of vector control, especially during the rainy season because there are potential breeding places for vectors inside and outside the home [20], [21].

$\mathrm{DHF}$ is an endemic disease throughout the tropics and parts of the subtropics [22]. The results of previous studies [23] show that dengue transmission in southern Italy has been detected in non-endemic areas. Aedes albopictus is considered as a vector that transmits dengue infection. The spread of DHF is influenced by the DENV-3 genotype sequence resulting in different tree phylogenetic in various worlds [23], [24] Environmental factors such as climate change are risk factors for disease incidence [25], [26]. Palembang City is an endemic area of DHF with a higher incidence and CFR when compared to other regencies/cities. The fluctuation of DHF cases during the 2015-2019 period in Palembang City, based on data from the Palembang City Health Office, in 2015 the number of DHF patients was 622 patients (IR 39.35/100,000) with a CFR of $0.16 \%$, then in 2016979 patients (IR 64.27/100,000) with $0.20 \%$ CFR. In 2017, there were 932 patients (IR $58.17 / 100,000$ ) with a CFR of $0.22 \%$, and in 2018 there were 693 patients (IR 44.49/100,000) with a CFR of $0.00144 \%$.

In 2019, the number of DHF cases increased drastically in numerous countries [27], including in Palembang, the capital city of the Indonesian province of South Sumatra. As attitudes, awareness, knowledge, and community behavior are fundamental in controlling DHF [1], [28], [29], this study aimed to determine the knowledge, attitudes and compliance with PSN 3M Plus strategies of those living in Palembang. It is anticipated that the study findings will help inform policymakers to modify or develop strategies for more effective DHF control and prevention, as well as increase community participation in DHF prevention programs.

\section{Methods}

\section{Study design and sample}

This observational, cross-sectional study was conducted in Palembang, a dengue-endemic area consisting of 18 urban villages and 107 villages, with a total area of $369.22 \mathrm{~km}^{2}$ and a population of $1,441,865$ (Figure 1). The 7 Ulu and Gandus urban villages were selected because they are urban villages with the highest number of dengue cases in Palembang. The study included all residents living in the urban village and the sample size was calculated based on equation 1:

$$
n=\frac{N}{1+N e^{2}}
$$

Where $n$ and $N$ are the minimum sample size and population size, respectively, and e is the percentage allowance for inaccuracy due to errors (10\%).

The Cluster Random Sampling method was used to recruit 200 respondents from August 2020 to 2021 and was conducted in strict adherence to the COVID-19 safety protocol. The respondents were aged 18-80 years with no history of mental illness. Before the questionnaire was given to the respondents, their home address and type of dwelling were recorded and they provided written informed consent. The questionnaire

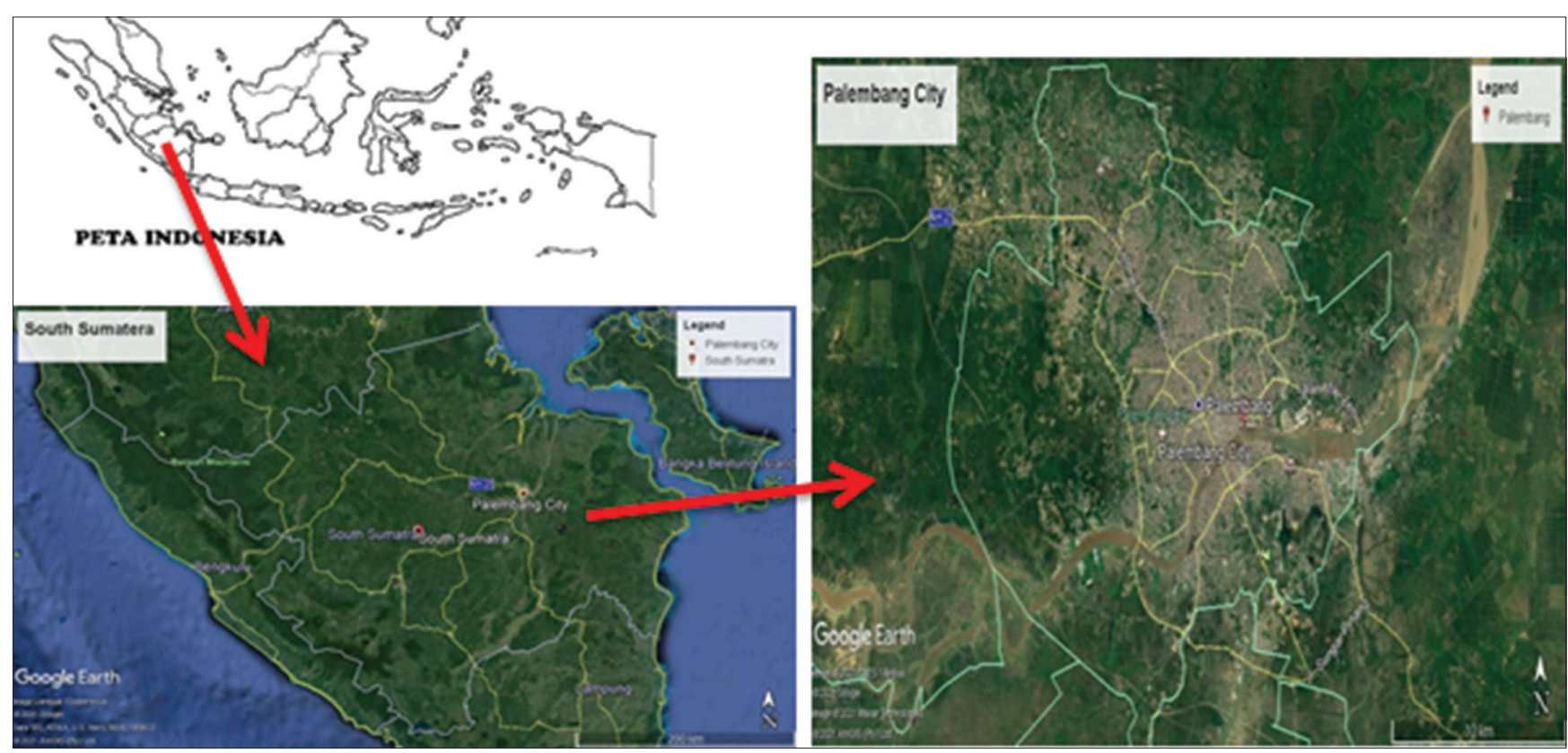

Figure 1: Map of Palembang 
comprised demographic profiles and characteristics of the respondents, their knowledge, attitudes, beliefs about dengue prevention, and their compliance with PSN $3 \mathrm{M}$ Plus DHF control measures. All research activities have been approved by the Health Research Ethics Committee (KEPK) Poltekkes Kemenkes Palembang, Indonesia (Certificate No: 1164/KEPK/Adm2/VIII/2021).

\section{Concept definition}

Public beliefs about health influence people's knowledge, treatment methods, and disease prevention behavior. Health beliefs are general perceptions of health and disease and the influence of sociodemographic characteristics, specifically, the respondents' knowledge about DHF consists of their understanding of its clinical symptoms, the risk of contracting DHF, treatment methods, disease vector modes of virus transmission, and prevention methods. After completing the first part of the interview about the respondents' sociodemographic characteristics, the questionnaire continued with questions focusing on knowledge, attitudes, and behavior. Each interview and survey took 20-40 min.

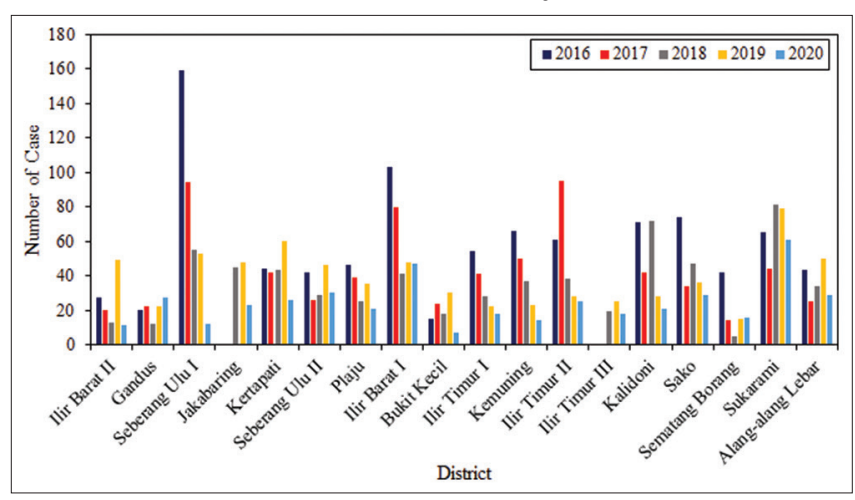

Figure 2: Number of DHF cases by district 2016-2020

\section{Data analysis}

The collected data were coded, entered into worksheets, corrected, and analyzed using SPSS (IBM SPSS 25). Descriptive statistics were applied to analyze the data and the Chi-square test was used to determine the relationships between variables. A p-value of less than 0.05 was considered statistically significant.

\section{Results}

\section{Dengue cases}

The incidence of dengue in Palembang has tended to fluctuate over the last 5 years, with the highest incidence of DHF reported in Seberang Ulu 1 urban village (414 cases) and the lowest incidence in the Gandus urban village (94 cases) (Figure 2). In the
7 Ulu urban village, which is part of the Seberang Ulu 1 urban village, there were 86 cases of dengue fever, with 37 cases in the Gandus village, part of the Gandus District, in 2015-2019 (Figure 3).

\section{Demographic characteristics of the respondents in Palembang city}

Of 163 respondents in the seven Ulu urban village, $81.5 \%$ were women, whereas, there were more male respondents $(63 ; 63.0 \%)$ in the Gandus urban village. The average age of respondents was $126(63.0 \%)$ and $83(83.0 \%)$ in seven Ulu and Gandus urban villages, respectively. Furthermore, as many as $120(60.0 \%)$ respondents in seven Ulu urban village had a low educational level in contrast to the Gandus urban village where only $31(31.0 \%)$ of the respondents had a low educational level. In total, $173(86.5 \%)$ respondents in seven Ulu Urban village and 93 (93\%) in Gandus urban village were employed (Table 1).

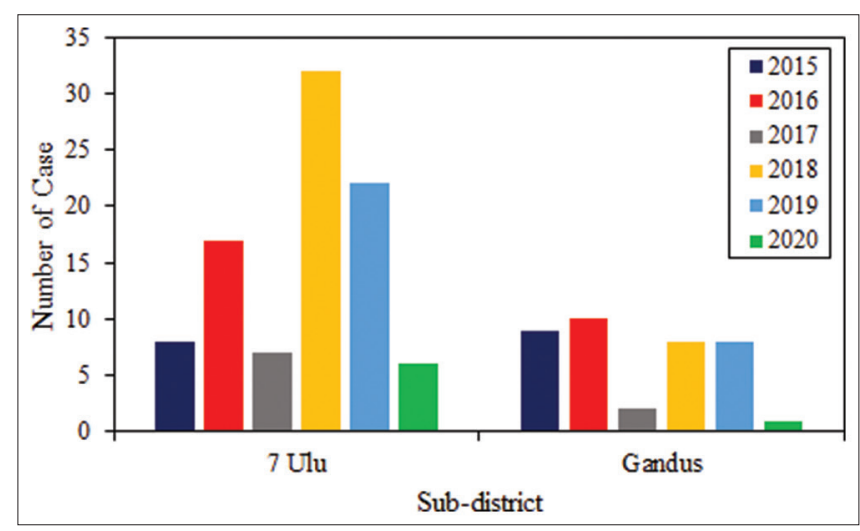

Figure 3: DHF incidence by urban village

The types of dwelling also varied between the seven Ulu and Gandus urban villages, with 118 (59.0\%) of the respondents in seven Ulu urban village living in a single storey house and $58(58.0 \%)$ of the respondents lived in such houses in Gandus. Environmental sanitation in seven Ulu urban village was categorized as dirty as poor as many as 112 houses (56.0\%), while in Gandus urban village, in as many 64 houses (64.0\%). Regarding population density in seven Ulu urban villages, there are 96 occupancy densities (48.0\%), while in the Gandus

Table 1: Characteristics of respondent

\begin{tabular}{|c|c|c|c|c|}
\hline \multirow{2}{*}{ Characteristics } & \multicolumn{2}{|c|}{ Seven Ulu } & \multicolumn{2}{|c|}{ Gandus } \\
\hline & $n$ & $\%$ & $n$ & $\%$ \\
\hline \multicolumn{5}{|l|}{ Gender } \\
\hline Woman & 163 & 81.5 & 37 & 37.0 \\
\hline Man & 37 & 18.5 & 63 & 63.0 \\
\hline \multicolumn{5}{|l|}{ Age } \\
\hline Old & 126 & 63.0 & 83 & 83.0 \\
\hline Young & 74 & 37.0 & 17 & 17.0 \\
\hline \multicolumn{5}{|l|}{ Last education } \\
\hline Low & 120 & 60.0 & 31 & 31.0 \\
\hline Higher & 80 & 40.0 & 69 & 69.0 \\
\hline \multicolumn{5}{|l|}{ Daily activities } \\
\hline Work & 173 & 86.5 & 93 & 93.0 \\
\hline Does not & 27 & 13.5 & 7 & 7.0 \\
\hline
\end{tabular}

urban village, both population density and occupancy density were categorized as not dense (Table 2). 
Table 2: Environmental demographics

\begin{tabular}{|c|c|c|c|c|}
\hline \multirow[t]{2}{*}{ Environmental demographics } & \multicolumn{2}{|c|}{$7 \mathrm{Ulu}$} & \multicolumn{2}{|c|}{ Gandus } \\
\hline & $\mathrm{n}$ & $\%$ & $\mathrm{n}$ & $\%$ \\
\hline \multicolumn{5}{|l|}{ Type of house } \\
\hline One floor & 118 & 59.0 & 58 & 58.0 \\
\hline Graded & 82 & 41.0 & 42 & 42.0 \\
\hline \multicolumn{5}{|l|}{ Environment sanitation } \\
\hline Dirty & 112 & 56.0 & 64 & 64.0 \\
\hline Sanitarian & 88 & 44.0 & 36 & 36.0 \\
\hline \multicolumn{5}{|c|}{ Type of water reservoir is favored by mosquitoes } \\
\hline Yes & 123 & 61.5 & 72 & 72.5 \\
\hline No & 77 & 38.5 & 28 & 28.0 \\
\hline \multicolumn{5}{|l|}{ Occupancy density } \\
\hline Yes & 96 & 48.0 & 26 & 26.0 \\
\hline No & 104 & 52.0 & 74 & 74.0 \\
\hline \multicolumn{5}{|l|}{ Population density } \\
\hline Yes & 167 & 83.5 & 25 & 25.0 \\
\hline No & 33 & 16.5 & 75 & 75.0 \\
\hline \multicolumn{5}{|l|}{ The existence of hanging clothes } \\
\hline Yes & 87 & 43.5 & 39 & 39.0 \\
\hline No & 113 & 56.5 & 61 & 61.0 \\
\hline \multicolumn{5}{|l|}{ Waste management } \\
\hline Right & 95 & 47.5 & 64 & 64.0 \\
\hline Not exactly & 105 & 52.5 & 36 & 36.0 \\
\hline \multicolumn{5}{|l|}{ Breading habit (Spot) } \\
\hline$\geq 3$ & 90 & 45.0 & 62 & 62.0 \\
\hline$<3$ & 110 & 55.0 & 38 & 38.0 \\
\hline \multicolumn{5}{|l|}{ Reasting habit (Spot) } \\
\hline$\geq 3$ & 84 & 42.0 & 39 & 39.0 \\
\hline$<3$ & 116 & 58.0 & 61 & 61.0 \\
\hline \multicolumn{5}{|l|}{ Mosquito repellent plant } \\
\hline No existence & 187 & 93.5 & 92 & 92.0 \\
\hline Existence & 13 & 6.5 & 8 & 8.0 \\
\hline
\end{tabular}

\section{PSN 3M Plus compliance on seven Ulu and Gandus urban villages}

The survey revealed that most respondents in both villages have tried to comply with the PSN 3 $\mathrm{M}$ Plus strategy recommendations but only a small proportion did so correctly. The most commonly used DHF control measure was the addition of larvicides to water reservoirs (Table 3).

Table 3: PSN 3 M Plus behavior

\begin{tabular}{|c|c|c|c|c|}
\hline \multirow[t]{2}{*}{ PSN 3 M Plus } & \multicolumn{2}{|c|}{7 Ulu } & \multicolumn{2}{|c|}{ Gandus } \\
\hline & $\mathrm{n}$ & $\%$ & $\mathrm{n}$ & $\%$ \\
\hline \multicolumn{5}{|c|}{$\begin{array}{l}\text { Drain and scrub water reservoirs such as bathtubs, vases, dispose of residual water in } \\
\text { the dispenser and back of the refrigerator once a week }\end{array}$} \\
\hline No & 16 & 8.0 & 11 & 11.0 \\
\hline Yes & 184 & 92.0 & 89 & 89.0 \\
\hline \multicolumn{5}{|c|}{ Close tightly all water reservoirs such as bathtubs and drums } \\
\hline No & 20 & 10.0 & 15 & 15.0 \\
\hline Yes & 180 & 90.0 & 85 & 85.0 \\
\hline \multicolumn{5}{|c|}{ Bury used items and do not let used items scatter } \\
\hline No & 26 & 13.0 & 33 & 33.0 \\
\hline Yes & 174 & 87.0 & 67 & 67.0 \\
\hline \multicolumn{5}{|c|}{ Keeping fish that eat mosquito larvae } \\
\hline No & 192 & 96.0 & 96 & 96.0 \\
\hline Yes & 8 & 4.0 & 4 & 4.0 \\
\hline \multicolumn{5}{|c|}{ Installing screens on windows and ventilation } \\
\hline No & 149 & 74.5 & 26 & 26.0 \\
\hline Yes & 51 & 25.5 & 74 & 74.0 \\
\hline \multicolumn{5}{|c|}{ Putting used clothes in a closed container } \\
\hline No & 101 & 50.5 & 51 & 51.0 \\
\hline Yes & 99 & 49.5 & 49 & 49.0 \\
\hline \multicolumn{5}{|c|}{ Giving larvicide to water reservoirs that are difficult to drain } \\
\hline No & 194 & 97.0 & 96 & 96.0 \\
\hline Yes & 6 & 3.0 & 4 & 4.0 \\
\hline \multicolumn{5}{|c|}{ Repairing drains and gutters that are not smooth } \\
\hline No & 16 & 8.0 & 90 & 90.0 \\
\hline Yes & 184 & 92.0 & 10 & 10.0 \\
\hline \multicolumn{5}{|c|}{ Check the larvae in the water storage periodically } \\
\hline No & 118 & 59.0 & 85 & 85.0 \\
\hline Yes & 82 & 41.0 & 15 & 15.0 \\
\hline \multicolumn{5}{|c|}{ Using insecticide } \\
\hline No & 11 & 5.5 & 5 & 5.0 \\
\hline Yes & 189 & 94.5 & 95 & 95.0 \\
\hline \multicolumn{5}{|c|}{ Using mosquito repellent plants } \\
\hline No & 187 & 93.5 & 82 & 82.0 \\
\hline Yes & 13 & 6.5 & 18 & 18.0 \\
\hline
\end{tabular}

Knowledge of the Palembang city dwellers

\section{regarding dengue and its transmission}

The respondents' knowledge in seven Ulu and Gandus urban villages about symptoms, transmission modes, and prevention of DHF was excellent (Table 4).

Table 4: Respondent's knowledge

\begin{tabular}{|c|c|c|c|c|}
\hline \multirow[t]{2}{*}{ Knowledge } & \multicolumn{2}{|c|}{$7 \mathrm{Ulu}$} & \multicolumn{2}{|c|}{ Gandus } \\
\hline & $\mathrm{n}$ & $\%$ & $\mathrm{n}$ & $\%$ \\
\hline \multicolumn{5}{|c|}{$\begin{array}{l}\text { High fever, suddenly } 2-7 \text { days and there are red spots on the skin is one of the clinical } \\
\text { symptoms of dengue disease }\end{array}$} \\
\hline Not exactly & 91 & 45.5 & 49 & 49.0 \\
\hline Right & 109 & 54.5 & 51 & 51.0 \\
\hline \multicolumn{5}{|c|}{ Dengue is transmitted through mosquito bites } \\
\hline Not exactly & 20 & 10.0 & 12 & 12.0 \\
\hline Right & 180 & 90.0 & 88 & 88.0 \\
\hline \multicolumn{5}{|c|}{ DHF mosquitoes bite during the day } \\
\hline Not exactly & 80 & 40.0 & 33 & 33.0 \\
\hline Right & 120 & 60.0 & 67 & 67.0 \\
\hline \multicolumn{5}{|c|}{ Summer is the perfect time for DHF mosquitoes to hatch } \\
\hline Not exactly & 13 & 6.5 & 3 & 3.0 \\
\hline Right & 187 & 93.5 & 97 & 97.0 \\
\hline \multicolumn{5}{|c|}{ DHF mosquitoes breed in dirty water } \\
\hline Not exactly & 114 & 57.0 & 57 & 57.0 \\
\hline Right & 86 & 43.0 & 43 & 43.0 \\
\hline \multicolumn{5}{|c|}{ Dengue is transmitted by Aedes aegypti and Aedes albopictus mosquitoes } \\
\hline Not exactly & 118 & 59.0 & 59 & 59.0 \\
\hline Right & 82 & 41.0 & 41 & 41.0 \\
\hline \multicolumn{5}{|c|}{$\begin{array}{l}\text { Having a black body with white stripes (white stripes) all over the body is one of the } \\
\text { characteristics of dengue-transmitting mosquitoes }\end{array}$} \\
\hline Not exactly & 104 & 52.0 & 53 & 53.0 \\
\hline Right & 96 & 48.0 & 47 & 47.0 \\
\hline \multicolumn{5}{|c|}{ The most effective way to eradicate DHF PSN 3M PLUS } \\
\hline Not exactly & 35 & 17.5 & 21 & 21.0 \\
\hline Right & 165 & 82.5 & 79 & 79.0 \\
\hline \multicolumn{5}{|c|}{ Bathtubs and jars that are not covered are breeding grounds for mosquitoes. } \\
\hline Not exactly & 60 & 30.0 & 29 & 29.0 \\
\hline Right & 140 & 70.0 & 71 & 71.0 \\
\hline \multicolumn{5}{|c|}{$\begin{array}{l}\text { Draining the bathtub is done once a week, then the eggs and mosquito larvae that exist } \\
\text { will also be drained }\end{array}$} \\
\hline Not exactly & 73 & 36.5 & 35 & 35.0 \\
\hline Right & 127 & 63.5 & 65 & 65.0 \\
\hline \multicolumn{5}{|c|}{$\begin{array}{l}\text { Changing the water in the vase, removing the water dispenser and the back of the } \\
\text { refrigerator prevent mosquito breeding grounds }\end{array}$} \\
\hline Not exactly & 128 & 64.0 & 64 & 64.0 \\
\hline Right & 72 & 36.0 & 36 & 36.0 \\
\hline
\end{tabular}

\section{Attitude and beliefs of the Palembang city dwellers regarding dengue}

The knowledge about DHF among respondents in both villages is high, however, their compliance with the PSN $3 \mathrm{M}$ Plus recommendations was far from satisfactory. Non-compliance can be explained by the respondents' attitude and beliefs, with most respondents believing that fogging is the most effective way to eradicate DHF and that the Government should be held accountable for DHF control (Table 5).

Table 5: Respondent's attitude

\begin{tabular}{|c|c|c|c|c|c|}
\hline \multirow[t]{2}{*}{ Attitude } & \multicolumn{2}{|c|}{7 Ulu } & \multicolumn{3}{|c|}{ Gandus } \\
\hline & $\mathrm{n}$ & $\%$ & $\mathrm{n}$ & $\%$ & \\
\hline \multicolumn{6}{|c|}{ DHF as health problem } \\
\hline No & 148 & 74.0 & 74 & 74.0 & \\
\hline Yes & 52 & 26.0 & 26 & 26.0 & \\
\hline \multicolumn{6}{|c|}{ Effective efforts in controlling DHF } \\
\hline PSM 3M Plus & 60 & 30.0 & 34 & 34.0 & \\
\hline Fogging & 140 & 70.0 & 66 & 66.0 & \\
\hline \multicolumn{6}{|c|}{ Responsible for DHF control } \\
\hline Government & 124 & 62.0 & 62 & 62.0 & \\
\hline Public & 76 & 38.0 & 38 & 38.0 & \\
\hline \multicolumn{6}{|c|}{$\begin{array}{l}\text { If any family member has a high fever, nosebleed, and red spots on the skin, I will take my } \\
\text { family member directly to the health service. }\end{array}$} \\
\hline No & 10 & 5.0 & 6 & & 6.0 \\
\hline Yes & 190 & 95.0 & 94 & & 94.0 \\
\hline \multicolumn{6}{|c|}{$\begin{array}{l}\text { Report to the head sub-district if there is a family member affected by DHF to prevent } \\
\text { transmission of DHF }\end{array}$} \\
\hline No & 3 & 1.5 & 1 & & 1.0 \\
\hline Yes & 197 & 98.5 & 99 & & 99.0 \\
\hline
\end{tabular}




\section{The relationship between $3 M$ plus $P S N$} behavior and the incidence of dengue fever in 7 Ulu and Gandus urban village

In the seven Ulu Urban village, there is a significant relationship between compliance with the 3M PLUS PSN and the incidence of DHF ( $p=0.000)$, while there was no significant relationship in Gandus ( $p=0.165$ ) (Table 6). Good Aedes spp vector control and prevention behavior reduce the risk of dengue fever transmission [26] and there was a significant relationship $(p=0.010)$ between the incidence of DHF and compliance with the PSN 3 M Plus [27]. Khon et al. [28] stated that people who are less active in draining water reservoirs regularly have a higher risk of dengue There is a correlation between the using lids to cover water containers and the incidence of DHF $(p=0.000)$, which is in line with a previous study by Rakmani et al., [17] but in contrast to Lin et al. [29], who reported no difference in risk between mosquito breeding sites when using closed and open containers.

Wong et al. [30] reported that an effective method to prevent mosquito breeding is adding larvacide (Temephos) to stored water, however, communities in the study area only dispose of water and drain new water without draining and cleaning the containers, not following the Ministry of Health and 3M Plus programs. Gan et al. [31] reported that most respondents in a study conducted in rural North Dharmapur, Gaibandha Bangladesh replaced water container lids immediately after use, drained and clean water collection containers weekly, kept drainage systems around the house free from debris, and used house mosquito repellent plants and mosquito nets [23]. Msellemu et al. [32] also reported that most surveyed people living in Dar es Salaam, Tanzania believed that mosquito nets could prevent dengue fever and some thought that dengue fever could be spread from person to person.

\section{Relationship between respondents'} characteristics and PSN 3M Plus behavior in seven Ulu and Gandus subdistricts

The research has shown that there is a statistically significant correlation between compliance to PSN 3M Plus ( $p=0.002$ ) and education in seven Ulu and between compliance to PSN 3M Plus and employment status in Gandus urban village $(p=0.000)$ (Table 7).

\section{Gender}

There was no relationship between gender and compliance with the PSN 3 M Plus. Members of the local community, both male and female, should be taking action to eradicate DHF vector, especially around schools and hospitals, to control the dengue epidemic.

\section{Age}

There was no relationship between age and compliance with PSN 3 M Plus. Theoretically, older individuals have better compliance and adherence to the PSN 3 M Plus.

\section{Education}

Employment status dramatically influenced compliance and adherence to the PSN 3 M Plus. Our study found that employed respondents (civil servants, private sector employees, and laborers) were too tired to strictly follow the recommended prevention measures, using insecticide spray, electric repellers, or burning mosquito breeding nets to avoid mosquito bites. Similar results were reported by Wong et al. [30] according to Lin et al. [29], [31], [32] workers tend to have better prevention practices compared to office workers $(p<0.05)$. The results of previous studies [31], [32], [33], [34], [35] were similar to the PSN 3M Plus control study which stated a relationship between adherence to the program and education. People with a university degree show better compliance than those who lack higher education, thus, education is an essential aspect of dengue infection control. In contrast, a study by Sukesi et al. [32] showed that individuals with higher education status show lower compliance with DHF prevention practices.

\section{Occupation}

Employment status can be a predisposing factor to inhibit or encourage a person's actions to eradicate mosquito nests. In general, people who have a job do not have time to carry out PSN. The study revealed that respondents who work show lower compliance with DHF prevention practices than those who do not work or are housewives, in line with the previous study, which stated that DHF prevention practices were mainly conducted by unemployed respondents [12], [36].

Table 6: The relationship between behavior and the incidence of DHF

\begin{tabular}{|c|c|c|c|c|c|c|c|c|c|c|c|c|c|c|}
\hline \multirow[t]{4}{*}{$\overline{\mathrm{DHF}}$} & \multicolumn{14}{|c|}{ Prilaku PSN 3 M Plus n (\%) } \\
\hline & \multicolumn{7}{|c|}{7 Ulu } & \multicolumn{7}{|c|}{ Gandus } \\
\hline & \multicolumn{2}{|c|}{ Not good } & \multicolumn{2}{|c|}{ Good } & \multirow{2}{*}{$\begin{array}{l}\text { Total } \\
\mathrm{n}\end{array}$} & \multirow[t]{2}{*}{$p$-value } & \multirow[t]{2}{*}{ OR } & \multicolumn{2}{|c|}{ Not good } & \multicolumn{2}{|c|}{ Good } & \multirow[t]{2}{*}{ Total } & \multirow[t]{2}{*}{$p$-value } & \multirow[t]{2}{*}{ OR } \\
\hline & $\mathrm{n}$ & $\%$ & $\mathrm{n}$ & $\%$ & & & & $\mathrm{n}$ & $\%$ & $\mathrm{n}$ & $\%$ & & & \\
\hline Yes & 22 & 84.6 & 4 & 15.4 & 26 & $0.000^{\star \star}$ & 9.000 & 7 & 9.3 & 68 & 90.7 & 75 & $0.165^{*}$ & 0.412 \\
\hline No & 66 & 37.9 & 108 & 62.1 & 174 & & $2.971-27.268$ & 5 & 20.0 & 20 & 80.0 & 25 & & $0.118-1.439$ \\
\hline
\end{tabular}


Table 7: Relationship between respondent characteristics and PSN 3M Plus behavior

\begin{tabular}{|c|c|c|c|c|c|c|c|c|c|c|c|c|c|c|}
\hline \multirow[t]{4}{*}{ Variable } & \multicolumn{14}{|c|}{ DHF incident $\mathbf{n}(\%)$} \\
\hline & \multicolumn{7}{|c|}{7 Ulu } & & & \multicolumn{4}{|c|}{ Gandus } & \multirow[t]{3}{*}{ OR } \\
\hline & \multicolumn{2}{|c|}{ Not good } & \multicolumn{2}{|c|}{ Good } & \multirow{2}{*}{$\begin{array}{l}\text { Total } \\
\mathbf{n}\end{array}$} & \multirow[t]{2}{*}{$p$-value } & \multirow[t]{2}{*}{ OR } & \multicolumn{2}{|c|}{ Not good } & \multicolumn{2}{|c|}{ Good } & \multirow[t]{2}{*}{ Total } & \multirow[t]{2}{*}{$p$-value } & \\
\hline & $\mathrm{n}$ & $\%$ & $\mathrm{n}$ & $\%$ & & & & $\mathrm{n}$ & $\%$ & $\mathrm{n}$ & $\%$ & & & \\
\hline Gender & & & & & & $0.116^{*}$ & 1.820 & & & & & & & \\
\hline Woman & 76 & 46.6 & 87 & 53.4 & 163 & & $0.856-3.868$ & 36 & 37.9 & 59 & 62.1 & 95 & $0.649^{*}$ & 2.441 \\
\hline Man & 12 & 32.4 & 25 & 67.6 & 37 & & & 1 & 20.0 & 4 & 80.0 & 5 & & $0.262-22.702$ \\
\hline \multicolumn{15}{|l|}{ Age } \\
\hline Old & 54 & 42.9 & 72 & 57.1 & 126 & $0.782^{*}$ & 0.882 & 60 & 72.3 & 23 & 27.7 & 83 & $0.226^{*}$ & 0.348 \\
\hline young & 34 & 45.9 & 40 & 45.1 & 74 & & $0.495-1.572$ & 15 & 88.2 & 2 & 11.8 & 17 & & $0.074-1.642$ \\
\hline \multicolumn{15}{|l|}{ Last education } \\
\hline Low & 66 & 55.0 & 54 & 45.0 & 120 & $0.000^{\star *}$ & 3.222 & 19 & 61.3 & 12 & 38.7 & 31 & $0.061^{*}$ & 0.368 \\
\hline Higher & 22 & 27.5 & 58 & 72.5 & 80 & & $1.754-5.921$ & 56 & 81.2 & 13 & 18.8 & 69 & & $0.143-0.942$ \\
\hline \multicolumn{15}{|l|}{ Daily activities } \\
\hline Work & 84 & 48.6 & 89 & 51.4 & 173 & $0.002^{\star *}$ & 5.427 & 92 & 98.9 & 1 & 1.1 & 93 & $0.000^{* *}$ & 112.667 \\
\hline Does not work & 4 & 14.8 & 23 & 85.2 & 27 & & $1.801-16.350$ & 3 & 42.9 & 4 & 57.1 & 7 & & $10.327-1457.030$ \\
\hline
\end{tabular}

*No relationship. **There is relationship.

Relationship between knowledge and compliance with PSN 3 M Plus in seven Ulu and Gandus urban villages

In the Urban village of 7 Ulu, there was no relationship between the respondent's knowledge and compliance with PSN 3 M Plus ( $p=0.635$ ), while in Gandus urban village, there was such a relationship $(p=0.000)$. DHF prevention practices are shown in Table 8. A more personal and practical approach to health education programs may be needed to influence behavior change. People need to have good knowledge about the signs and symptoms of the disease, its transmission modes, and transmission vectors to prevent disease transmission. The expected behavior is defined in the Mosquito Nest Eradication (PSN) effort, however, knowledge does not always result in good practice.

\section{Relationship between attitude and compliance with PSN 3 M Plus in 7 Ulu and Gandus urban villages}

There is a relationship between the attitude of the respondent $(p=0.027)$ and compliance with PSN 3M Plus $(p=0.000$ ) in both villages (Table 9). Ghani et al. [39] showed that attitude does not influence DHF prevention practices $(p=0.101)$, however, the results from previous research showed that there is a significant relationship between the two variables [39], [40], [41], [42]. Attitude can influence people's behavior. Rahman et al. [37] describe attitude as evaluation of a psychological object, either positive or negative, which can be classified into at least three terms of thought. First, a frame of mind where an attitude is a form of evaluation or reaction to the feelings one has, be it a favorable or unfavorable attitude. Second, the attitude framework is a kind of readiness to react to an object in a certain way. Third, oriented to the triadic scheme. According to this framework, an attitude is a combination of cognitive, affective, and conative components that interact with each other in understanding, feeling, and behaving toward an object. Based on the health behavior theory put forward by Guad et al. [1], [38], a person's actions or practices are formed from someone's knowledge and the tendency to act in a person is one of the main components of a person's attitude [39].

\section{Discussion}

The global incidence of DHF has increased dramatically in the last few decades and coupled with the Covid-19 pandemic, can cause death. DHF is a viral infection transmitted via arthropods to humans that attacks the immune system. The DHF outbreaks in Palembang are not spontaneous but closely related to the season. Furthermore, DHF prevention is not only the responsibility of the government or healthcare workers, it requires broad community participation in the $3 \mathrm{M}$ movement to effectively eradicate mosquito nests, closing chambers, burying, and draining.

PSN 3M Plus was introduced a relatively long time ago but is often considered a slogan and the knowledge is not put into practice. Local communities may have excellent knowledge regarding the dangers of DHF but activities to eradicate mosquito breeding grounds are still lacking. Research by Guan et al. [40] and Xu et al., [1], Alwan et al., [41] show that the level of knowledge does not correlate with actual vector control practices. Knowledge about the transmission of dengue fever is high but the control of $A$. aegypti mosquitoes is still low. Kumaran et al., [42] showed that negative habits were challenging to break even though health promotion campaigns have been conducted.

Table 8: Relationship between knowledge and compliance with PSN 3 M Plus

\begin{tabular}{|c|c|c|c|c|c|c|c|c|c|c|c|c|c|c|}
\hline \multirow[t]{4}{*}{ Knowledge } & \multicolumn{14}{|c|}{ PSN 3M Plus behavior (\%) } \\
\hline & \multicolumn{7}{|c|}{$7 \mathrm{Ulu}$} & \multicolumn{6}{|c|}{ Gandus } & \multirow[t]{3}{*}{ OR } \\
\hline & \multicolumn{2}{|c|}{ Not good } & \multicolumn{2}{|c|}{ Good } & \multirow{2}{*}{$\begin{array}{l}\text { Total } \\
\mathrm{n}\end{array}$} & \multirow[t]{2}{*}{$\mathrm{p}$-value } & \multirow[t]{2}{*}{ OR } & \multicolumn{2}{|c|}{ Not good } & \multicolumn{2}{|c|}{ Good } & \multirow[t]{2}{*}{ Total } & \multirow[t]{2}{*}{$p$-value } & \\
\hline & $\mathrm{n}$ & $\%$ & $\mathrm{n}$ & $\%$ & & & & $\mathrm{n}$ & $\%$ & $\mathrm{n}$ & $\%$ & & & \\
\hline Not good & 36 & 46.8 & 41 & 53.3 & 77 & $0.635^{*}$ & 1.199 & 51 & 91.1 & 5 & 8.9 & 56 & $0.000^{* *}$ & 8.500 \\
\hline Good & 52 & 42.3 & 71 & 57.7 & 123 & & $0.676-2.126$ & 24 & 54.5 & 20 & 45.5 & 44 & & $2.848-25.370$ \\
\hline
\end{tabular}


Public knowledge about the dengue virus and its transmission process can be increased by developing, modifying, and intervening in the community controlling DHF. Slum settlements and poor sanitation in Palembang were risk factors for the incidence of dengue disease. In line with previous studies [43], population density, residential density, and environmental sanitation were closely associated with the incidence of DHF and effective prevention methods, especially during the rainy season [19].

DHF prevention is a shared responsibility, for example, fogging is routinely performed by the Health Office but this only kills the adult mosquitoes, therefore does not eliminate the risk of DHF transmission. Fogging cannot kill the larvae in stagnant water, so 3M prevention must still be conducted by the community such as closing or covering water containers, draining stagnant water reservoirs, and burying all objects that have the potential to be used as water reservoirs, for example, used cans or used tyres, that could potentially be a mosquito breeding site.

Respondents believed that DHF was a global health threat in all countries but that fogging is the most effective method to prevent DHF, with most respondents believing that the Government is the most responsible for DHF management. When exposed to dengue infection, the people of Palembang city sought immediate treatment at a private hospital to get the best service, which is consistent with other studies [19], [44], [45], [46]. Respondents were not applying larvicides to water reservoirs that are difficult to drain in contrast to a report by Kumosani et al., [46] whereby larvacide (Temephos) or chemicals were added to water storage containers to prevent mosquito breeding.

Even though the respondents were aware of the $3 \mathrm{M}$ plus strategy, they did not put this into practice. Those who should have drained and cleaned the water containers just threw away the old water and filled the container [1], [46], most people used lids to cover water containers, drained and cleaned water containers weekly, kept drainage systems around the house clear of debris, and used house mosquito repellent plants and mosquito nets [46], [47]. A study conducted in Dar es Salaam, Tanzania, [48] reported that most respondents considered that mosquito nets could prevent dengue fever, while some thought that dengue was spread from person to person.

Chandren et al. [13] reported that people in Hong Kong stated that DHF is not a threat. believing that $\mathrm{DHF}$ is not dangerous if a person has initial treatment.
Most respondents demonstrated good attitudes and beliefs about dengue outbreaks, taking action to protect against dengue and mosquito bites. Television, radio, and newspapers are the most crucial information channels regarding dengue [13]. In Pakistan, most respondents claimed that they are knowledgeable about dengue infection [1], [49], that this disease is spread by mosquitoes and dengue fever is more common in the rainy season. However, in contrast to Shan Timur Special Region IV, Myanmar, their knowledge of DHF is not sufficient. However, dengue prevention practices have been put in place and they believe that knowledge is not from the educational background but experience [50].

The present study showed that most families surveyed had experienced DHF. Clean water is a place for mosquitoes to breed. The correct PSN 3M Plus of DHF control measures have been discussed on television and by health department promotion teams. However, the results obtained are inversely proportional to the gap between knowledge and practice of preventing dengue. Most people of Palembang city believe that dengue prevention is the full responsibility of the health department and that the most effective prevention is fogging. Education is not related to dengue prevention practices but the respondent's employment status is very influential.

Good knowledge is not associated with the adoption of dengue prevention measures [1], [12]. In response to each incidence of $\mathrm{DHF}$, the respondent takes action to drain and clean the water reservoir of mosquito eggs that might stick to the container. Lack of knowledge and poor adherence to DHF prevention guidelines in the community will increase the morbidity due to DHF [9]. The present study revealed that the practice of controlling PSN $3 \mathrm{M}$ Plus is associated with education. A person with a bachelor's degree has a better practice attitude than other educational groups. Education shows a higher probability of dengue control practices and attitudes. Furthermore, education is an essential aspect of dengue infection control [36], however, according to Makrufardi et al. [38], respondents with higher education did not show better behaviour to prevent mosquito breeding. Also, employment in the present study dramatically affected compliance with PSN 3M Plus. Employees such as civil servants, private supervisors, and workers were too tired to implement vector control measures, instead of relying on avoiding mosquito bites by using insecticide spray, electric repellers or burn.

A limitation of this study is that all information obtained through interviews and reported practices

Table 9: The relationship between attitudes and compliance with PSN 3M Plus

\begin{tabular}{|c|c|c|c|c|c|c|c|c|c|c|c|c|c|c|}
\hline \multirow[t]{4}{*}{ Attitude } & \multicolumn{14}{|c|}{ DHF incident $\mathrm{n}(\%)$} \\
\hline & \multicolumn{7}{|c|}{7 Ulu } & \multicolumn{6}{|c|}{ Gandus } & \multirow[t]{3}{*}{ OR } \\
\hline & \multicolumn{2}{|c|}{ Not good } & \multicolumn{2}{|c|}{ Good } & \multirow{2}{*}{$\begin{array}{l}\text { Total } \\
\mathrm{n}\end{array}$} & \multirow{2}{*}{$p$-value } & \multirow{2}{*}{ OR } & \multicolumn{2}{|c|}{ Kurang baik } & \multicolumn{2}{|c|}{ Baik } & \multirow[t]{2}{*}{ Total } & \multirow[t]{2}{*}{$\mathrm{p}$-value } & \\
\hline & $\mathrm{n}$ & $\%$ & $\mathrm{n}$ & $\%$ & & & & $\mathrm{n}$ & $\%$ & $\bar{n}$ & $\%$ & & & \\
\hline$\overline{\text { Not good }}$ & 3 & 50.4 & 62 & 49.6 & 125 & $0.027^{\star \star}$ & 2.032 & 55 & 91.7 & 5 & 88.3 & 60 & $0.000^{* \star}$ & 11.000 \\
\hline Good & 25 & 33.3 & 50 & 66.7 & 75 & & $1.121-3.683$ & 20 & 50.0 & 20 & 50.0 & 40 & & $3.641-33.230$ \\
\hline
\end{tabular}


cannot be verified, as can responses to questions in attitude and practice. However, an important strength of this study is that respondents were recruited based on criteria across endemic areas. Results can be applied to general community settings. The eligibility criteria further strengthen the quality of the findings.

\section{Conclusion}

Vector control practices are essential for the prevention and control of DHF. Household-level environmental modifications can be a cost-effective approach to reduce the incidence of DHF, however, there is a need to raise public awareness via preventive campaigns as good knowledge does not guarantee good compliance with PSN 3M Plus recommendations. Health promotion activities should increase public awareness about the importance of eradicating breeding grounds around households. It is also recommended that regular dengue health education programmes target all age groups and promote the planting of mosquito repellent plants as safe and environmentally friendly vector control.

\section{References}

1. Xu Z, Bambrick H, Frentiu FD, Devine G, Yakob L, Williams G, et al. Projecting the future of dengue under climate change scenarios: Progress, uncertainties and research needs. PLoS Negl Trop Dis. 2020;14(3):1-11. https://doi.org/10.1371/journal. pntd.0008118

\section{PMid:32119666}

2. Suwanbamrung $C$, Le $C N$, Maneerattanasak $S$, Satian $P$, Talunkphet $\mathrm{C}$, Nuprasert $\mathrm{Y}$, et al. Developing and using a dengue patient care guideline for patients admitted from households to primary care units and the district hospital: A community participatory approach in Southern Thailand. One Health. 2020;10:100168. https://doi.org/10.1016/j.onehlt.2020.100168 PMid:33117880

3. Wijesinghe A, Gamage J, Goonewardena H, Gomes L, Jayathilaka D, Wijeratne DT, et al. Phenotype and functionality of follicular helper $T$ cells in patients with acute dengue infection. J Biomed Sci. 2020;27(1):50. https://doi.org/10.1186/ s12929-020-00641-2

PMid:32264870

4. Vasey B, Shankar AH, Herrera BB, Becerra A, Xhaja K, Echenagucia $M$, et al. Multivariate time-series analysis of biomarkers from a dengue cohort offers new approaches for diagnosis and prognosis. PLoS Negl Trop Dis. 2020;14(6):e0008199. https://doi.org/10.1371/journal. pntd.0008199

PMid:32544159

5. Suwanbamrung $C$, Le CN, Phetphrom $P$, Kamneatdee $P$, Nontapet $\mathrm{O}$, Kaewket N. Factors correlated with practices regarding care of dengue patients among nurses from 94 primary care units in a high-risk province in Southern Thailand. J Multidiscip Healthc. 2020;13:2043-56. https://doi.org/10.2147/ JMDH.S286737

\section{PMid:33408478}

6. Kuna A, Gajewski M, Biernat B. Selected arboviral diseases imported to Poland-Current state of knowledge and perspectives for research. Ann Agric Environ Med. 2019;26(3):385-91. https:// doi.org/10.26444/aaem/102471

PMid:31559790

7. Pernat N, Kampen H, Ruland F, Jeschke JM, Werner D. Drivers of spatio-temporal variation in mosquito submissions to the citizen science project 'Mückenatlas.' Sci Rep. 2021;11(1):1356. https://doi.org/10.1038/s41598-020-80365-3

PMid:33446753

8. Manh DH, Weiss LN, van Thuong N, Mizukami S, Dumre SP, Luong QC, et al. Kinetics of CD4+ T helper and CD8+ effector $\mathrm{T}$ cell responses in acute dengue patients. Front Immunol. 2020;11:1980. https://doi.org/10.3389/fimmu.2020.01980

PMid:33072068

9. Fustec B, Phanitchat T, Hoq MI, Aromseree S, Pientong C, Thaewnongiew K, et al. Complex relationships between Aedes vectors, socio-economics and dengue transmission-lessons learned from a case-control study in Northeastern Thailand. PLoS Negl Trop Dis. 2020;14(10):e0008703. https://doi. org/10.1371/journal.pntd.0008703

PMid:33001972

10. Nguyen-Tien T, Pham LT, Vu DT, Tran SH, Vu LT, Bui VN, et al. Knowledge and practice on prevention of mosquitoborne diseases in livestock-keeping and non-livestock-keeping communities in Hanoi city, Vietnam: A mixed-method study. PLoS One. 2021;16(2):e0246032. https://doi.org/10.1371/ journal.pone.0246032

PMid:33539377

11. Xu JW, Liu H, Yaw B, Nbwi HS. The health beliefs, dengue knowledge and control behaviors among internally displaced persons versus local residents in kachin special region II, Myanmar. PLoS Negl Trop Dis. 2020;14(6):e0008321. https:// doi.org/10.1371/journal.pntd.0008321

PMid:32584822

12. Selvarajoo S, Liew JW, Tan W, Lim XY, Refai WF, Zaki RA, et al. Knowledge, attitude and practice on dengue prevention and dengue seroprevalence in a dengue hotspot in Malaysia: A cross-sectional study. Sci Rep. 2020;10(1):9534. https://doi. org/10.1038/s41598-020-66212-5

PMid:32533017

13. Chandren JR, Wong LP, AbuBakar S. Practices of dengue fever prevention and the associated factors among the Orang Asli in Peninsular Malaysia. PLoS Negl Trop Dis. 2015;9(8):e0003954. https://doi.org/10.1371/journal.pntd.0003954 PMid:26267905

14. Boonchutima S, Kachentawa K, Limpavithayakul M, Prachansri A. Longitudinal study of Thai people media exposure, knowledge, and behavior on dengue fever prevention and control. J Infect Public Health. 2017;10(6):836-41. https:// doi.org/10.1016/j.jiph.2017.01.016 PMid:28285970

15. Li L, Liu WH, Bin ZZ, Liu Y, Chen XG, Luo L, et al. The effectiveness of early start of Grade III response to dengue in Guangzhou, China: A population-based interrupted time-series study. PLoS Negl Trop Dis. 2020;14(8):e0008541. https://doi. org/10.1371/journal.pntd.0008541 PMid:32764758

16. Irda Sari SY, Adelwin Y, Rinawan FR. Land use changes and cluster identification of dengue hemorrhagic fever cases in Bandung, Indonesia. Trop Med Infect Dis. 2020;5(2):70. https:// 
doi.org/10.3390/tropicalmed5020070

PMid:32370258

17. Rakhmani AN, Limpanont $\mathrm{Y}$, Kaewkungwal J, Okanurak K. Factors associated with dengue prevention behaviour in Lowokwaru, Malang, Indonesia: A cross-sectional study. BMC Public Health. 2018;18(1):619. https://doi.org/10.1186/ s12889-018-5553-z

PMid:29751758

18. Ahbirami R, Zuharah WF. School-based health education for dengue control in kelantan, malaysia: Impact on knowledge, attitude and practice. PLoS Negl Trop Dis. 2020;14(3):e0008075. https://doi.org/10.1371/journal.pntd.0008075 PMid:32218580

19. Telle O, Nikolay B, Kumar V, Benkimoun S, Pal R, Nagpal B, et al. Social and environmental risk factors for dengue in Delhi city: Aretrospective study. PLoS Negl Trop Dis. 2021;15(2):e0009024. https://doi.org/10.1371/journal.pntd.0009024 PMid:33571202

20. Elsinga J, Lizarazo EF, Vincenti MF, Schmidt M, Velasco-Salas ZI, Arias $\mathrm{L}$, et al. Health seeking behaviour and treatment intentions of dengue and fever: A household survey of children and adults in Venezuela. PLoS Negl Trop Dis. 2015;9(12):e0004237. https://doi.org/10.1371/journal.pntd.0004237

PMid:26624283

21. Gawor J, Borecka A. Quantifying the risk of zoonotic geohelminth infections for rural household inhabitants in Centra Poland. Ann Agric Environ Med. 2017;24(1):44-8. https://doi. org/10.5604/12321966.1230679

PMid:28378972

22. Fabrizio C, Lepore L, Chironna M, Angarano G, Saracino A. Dengue fever in travellers and risk of local spreading: Case reports from Southern Italy and literature update. New Microbiol. 2017;40(1):11-8. PMid:28072887

23. Amir M, Hussain A, Asif M, Ahmed S, Alam H, Moga MA, et al. Full-length genome and partial viral genes phylogenetic and geographical analysis of dengue serotype 3 isolates. Microorganisms. 2021;9(2):323. https://doi.org/10.3390/ microorganisms 9020323 PMid:33557307

24. Pagani G, Zanchetta N, Galimberti L, Oreni L, Passerini S, Giacomelli A, et al. Imported dengue fever: A 16-years retrospective analysis in milan (Italy) and a brief review of the european literature. Infez Med. 2020;28(2):243-52. PMid:32487790

25. Baymakova M, Plochev K, Dikov I, Popov GT, MihaylovaGarnizova R, Kovaleva V, et al. Fever of unknown origin in a bulgarian hospital: Evaluation of 54 cases for a four year-period. J Clin Anal Med. 2016;7(1):70-5.

26. Rogers DJ, Suk JE, Semenza JC. Using global maps to predict the risk of dengue in Europe. Acta Trop. 2014;129(1):1-14. https://doi.org/10.1016/j.actatropica.2013.08.008

PMid:23973561

27. Chan EY, Lo ES, Huang Z, Lam HC, Yeung MP, Kwok KO, et al. Sociodemographic predictors of knowledge, mosquito bite patterns and protective behaviors concerning vector borne disease: The case of dengue fever in chinese subtropical city, hong kong. PLoS Negl Trop Dis. 2021;15(1):e0008993. https:// doi.org/10.1371/journal.pntd.0008993

PMid:33465094

28. Khon S, Seenprachawong U. The public demand for a dengue fever vaccine: A contingent valuation survey in Phnom Penh, Cambodia. Int J Econ Financ Issues. 2020;10(6):129-38.

29. Lin CT, Huang YS, Liao LW, Ting CT. Measuring consumer willingness to pay to reduce health risks of contracting dengue fever. Int J Environ Res Public Health. 2020;17(5):1810. https:// doi.org/10.3390/ijerph17051810

PMid:32164392

30. Wong LP, Shakir SMM, Atefi N, AbuBakar S. Factors affecting dengue prevention practices: Nationwide survey of the Malaysian public. PLoS One. 2015;10(4):e0122890. https://doi. org/10.1371/journal.pone. 0122890

PMid:25836366

31. Gan SJ, Leong YQ, Fakrul M, Wong ST, Wong SF, Mak JW, et al. Dengue fever and insecticide resistance in Aedes mosquitoes in Southeast Asia: A review. Parasit Vectors. 2021;14(1):315. https://doi.org/10.1186/s13071-021-04785-4 PMid:34112220

32. Sukesi TW, Satoto TB, Murhandarwati EH, Padmawati RS. Effects of health education based intervention on community's perception, healthy house, and social capital of dengue in endemic area of sleman regency Indonesia. Open Access Maced J Med Sci. 2021;9:428-36.

33. Diaz-Quijano FA, Martínez-Vega RA, Rodriguez-Morales AJ, Rojas-Calero RA, Luna-González ML, Díaz-Quijano RG. Association between the level of education and knowledge, attitudes and practices regarding dengue in the Caribbean region of Colombia. BMC Public Health. 2018;18(1):143. https:// doi.org/10.1186/s12889-018-5055-z

PMid:29338712

34. Stefopoulou A, Ladeau SL, Syrigou N, Balatsos G, Karras V, Lytra I, et al. Knowledge, attitude and practices survey in greece before the implementation of sterile insect technique against Aedes albopictus. Insects. 2021;12(3):212. https://doi. org/10.3390/insects 12030212

PMid:33801542

35. Nisha RR, Saravanabavan V, Balaji D. Knowledge, attitude and practice in dengue endemic areas in Madurai district. Int $\mathrm{J}$ Contemp Med Res. 2020;7(3):1-6.

36. Saefi M, Fauzi A, Kristiana E, Adi WC, Muchson M, Setiawan ME, et al. Survey data of COVID-19-related knowledge, attitude, and practices among indonesian undergraduate students. Data Brief. 2020;31:105855. https://doi.org/10.1016/j. dib.2020.105855 PMid:32607405

37. Rahman MS, Overgaard HJ, Pientong C, Mayxay M, Ekalaksananan T, Aromseree S, et al. Knowledge, attitudes, and practices on climate change and dengue in Lao People's Democratic Republic and Thailand. Environ Res. 2021;193:110509. https://doi.org/10.1016/j.envres.2020.110509 PMid:33245883

38. Makrufardi F, Phillabertha PS, Safika EL, Sungkono S. Factors associated with dengue prevention behaviour in riverbank area: A cross-sectional study. Ann Med Surg (Lond). 2021;66:102450. https://doi.org/10.1016/j.amsu.2021.102450

PMid:34141421

39. Ghani NA, Shohaimi S, Hee AK, Chee HY, Emmanuel O, Ajibola LS. Comparison of knowledge, attitude, and practice among communities living in hotspot and non-hotspot areas of dengue in Selangor, Malaysia. Trop Med Infect Dis. 2019;4(1):37. https://doi.org/10.3390/tropicalmed4010037 PMid:30781369

40. Guad RM, Wu YS, Aung YN, Sekaran SD, Wilke AB, Low WY, et al. Different domains of dengue research in malaysia: A systematic review and meta-analysis of questionnaire-based studies. Int J Environ Res Public Health. 2021;18(9):4474. https://doi.org/10.3390/ijerph18094474 PMid:33922427

41. Alwan MR, Elfituri F, Eltariki M, Munirah F, Aziz B. Assessment of knowledge, attitudes and practice toward dengue fever among University Students in Malaysia. Glob J Public Heal 
Med. 2021;3(1):289-300.

42. Kumaran E, Doum D, Keo V, Sokha L, Sam BL, Chan V, et al. Dengue knowledge, attitudes and practices and their impact on community-based vector control in rural Cambodia. PLoS Negl Trop Dis. 2018;12(2):e0006268. https://doi.org/10.1371/journal. pntd.0006268.

PMid:29451879

43. Saumya P, Shyam V. The menace of dermatophytosis in India: The evidence that we need. Indian J Dermatol Venereol Leprol. 2018;84(1):281-4. https://doi.org/10.4103/ijdvl.ijdvl_224_17 PMid:28366915

44. van Nguyen $H$, Than $P Q$, Nguyen $T H, V u ~ G T$, Hoang $C L$, Tran TT, et al. Knowledge, attitude and practice about dengue fever among patients experiencing the 2017 outbreak in vietnam. Int J Environ Res Public Health. 2019;16(6):976. https://doi.org/10.3390/ijerph16060976

PMid:30889912

45. Alghazali KA, Teoh BT, Sam SS, Abd-Jamil J, Johari J, Atroosh WM, et al. Dengue fever among febrile patients in Taiz city, Yemen during the 2016 war: Clinical manifestations, risk factors, and patients knowledge, attitudes, and practices toward the disease. One Health. 2020;9:100119. https://doi. org/10.1016/j.onehlt.2019.100119 PMid:32368608

46. Kumosani TA, Al-malki AL, Razvi SS, Balgoon MJ, Abualnaja KO, Barbour EK, et al. Hemorrhagic fever in Saudi Arabia: Challenge to public health, effective management and future considerations. Afr Health Sci. 2020;20(3):1153-63. https://doi.org/10.4314/ahs.v20i3.17

PMid:33402960

47. Li C, Lu Y, Liu J, Wu X. Climate change and dengue fever transmission in china: Evidences and challenges. Sci Total Environ. 2018;622-623(19):493-501. https://doi.org/10.1016/j. scitotenv.2017.11.326

PMid:29220773

48. Msellemu D, Gavana T, Ngonyani H, Mlacha YP, Chaki P, Moore SJ. Knowledge, attitudes and bite prevention practices and estimation of productivity of vector breeding sites using a habitat suitability score (Hss) among households with confirmed dengue in the 2014 outbreak in dar es salaam, tanzania. PLoS Negl Trop Dis. 2020;14(7):e0007278. https://doi.org/10.1371/ journal.pntd.0007278

PMid:32614855

49. Siddiqui MR, Velidi NR, Pati S, Rath N, Kanungo AK, Bhanjadeo $\mathrm{AK}$, et al. Integration of leprosy elimination into primary health care in Orissa, India. PLoS One. 2009;4(12):e8351. https://doi. org/10.1371/journal.pone. 0008351

PMid:20020051

50. Cheng J, Bambrick H, Yakob L, Devine G, Frentiu FD, Toan DT, et al. Heatwaves and dengue outbreaks in Hanoi, Vietnam: New evidence on early warning. PLoS Negl Trop Dis. 2020;14(1):e0007997. https://doi.org/10.1371/journal.pntd.0007997

PMid:31961869 